\title{
RESISTENSI TANAMAN KARET KLON IRR SERI 300 TERHADAP PENYAKIT GUGUR DAUN COLLETOTRICHUM DI SUMATERA SELATAN
}

\author{
Resistance of the IRR 300 Series Rubber Clones to Colletotrichum \\ Leaf Fall Disease at South Sumatera
}

\author{
Alchemi Putri Juliantika KUSDIANA*, Afdholiatus SYAFAAH, dan Sigit ISMAWANTO \\ Balai Penelitian Sembawa, Pusat Penelitian Karet \\ Jalan Raya Palembang - Pangkalan Balai KM 29 \\ PO BOX 1127 Palembang 30001 Sumatera Selatan \\ "Email : alchemiputri@yahoo.com
}

Diterima : 29 November 2018 / Disetujui : 27 Desember 2018

\begin{abstract}
Colletotrichum leaffall disease is one of the important diseases that can cause a decrease of latex production in rubber plantations. The most effective to controlling of Colletotrichum leaf fall disease is to use resistant clones. Identification of resistance levels of rubber clones IRR 300 series have been done in the laboratories and greenhouse by using completely randomized design with two factors, namely the type of rubber clone (26 clones) and Colletotrichum gloeosporioides isolate (three isolates: CG-PR 303, CG-RRIM 600, and CG-GT 1). In addition, direct field observation on immature rubber plants was also carried out. The results showed that all of the $\mathrm{C}$. gloeosporioides isolates gave a significant effect to the resistance of 22 rubber clones IRR 300 series both in the laboratory and greenhouse. CG-PR 303 isolate had the highest virulence level compared to other isolates. Based on all of the experiment conditions, it was concluded that 13 rubber clones i.e IRR 300, IRR 301, IRR 302, IRR 307, IRR 308, IRR 309, IRR 310, IRR 311, IRR 313, IRR 315, IRR 316, IRR 318, and $I R R 321$ had a high resistance to Colletotrichum leaffall disease.
\end{abstract}

Keywords: Colletotrichum gloeosporioides; detached leaf; screening; toxin; virulence

\footnotetext{
Abstrak

Penyakit gugur daun Colletotrichum merupakan salah satu penyakit penting yang dapat menyebabkan penurunan produksi lateks pada perkebunan karet. Pengendalian penyakit gugur daun
}

Colletotrichum yang paling efektif adalah dengan penggunaan klon resisten. Pengujian resistensi klon karet IRR seri 300 dilakukan di laboratorium dan rumah kaca dengan menggunakan rancangan acak lengkap dua faktor yaitu jenis klon (26 jenis klon) dan isolat C. gloeosporioides (tiga isolat: CG-PR 303, CG-RRIM 600, dan CG-GT 1). Selain itu, pengamatan serangan penyakit secara langsung juga dilakukan pada tanaman belum menghasilkan di lapangan. Hasil pengujian menunjukkan bahwa semua isolat C. gloeosporioides memiliki pengaruh nyata terhadap tingkat ketahanan 22 klon IRR seri 300 baik di laboratorium maupun di rumah kaca. Isolat CG-PR-303 memiliki tingkat virulensi paling tinggi dibandingkan isolat lainnya. Berdasarkan hasil pengamatan pada tiga kegiatan dapat disimpulkan bahwa 13 klon karet yaitu IRR 300, IRR 301, IRR 302, IRR 307, IRR 308, IRR 309, IRR 310, IRR 311, IRR 313, IRR 315, IRR 316, IRR 318, dan IRR 321 memiliki tingkat resistensi yang tinggi terhadap penyakit gugur daun Colletotrichum.

Kata kunci: Colletotrichum gloeosporioides; gugur daun; skrining; toksin; virulensi

\section{PENDAHULUAN}

Penyakit gugur daun Colletotrichum yang disebabkan oleh cendawan Colletotrichum gloeosporioides pertama kali dilaporkan di Sri Lanka pada tahun 1905 (Jayasinghe et al., 1997), kemudian menyebar ke negara lainnya seperti Malaysia pada tahun 1910, Uganda dan Zaire pada tahun 1914, Indonesia pada tahun 1918, Phillipina pada tahun 1927, Mexico pada 
tahun 1943, Brazil pada tahun 1944, Afrika dan Gabon pada tahun 1949, Cameroon pada tahun 1952, Papua pada tahun 1953, Ivory Coast pada tahun 1956, Afrika Tengah pada tahun 1958, dan China pada tahun 1962 (Shufen et al., 1999).

Penyakit gugur daun Colletotrichum merupakan salah satu penyakit yang banyak terjadi di seluruh negara penghasil karet. Penurunan produksi karet akibat penyakit ini sebesar $7-45 \%$ tergantung dari intensitas serangan patogen. Penyakit gugur daun Colletotrichum terdapat sepanjang tahun dan dapat menyerang semua tahapan usia daun karet, serta menyerang tanaman karet pada segala tingkatan umur, baik pada pembibitan, kebun entres, tanaman belum menghasilkan, maupun tanaman menghasilkan (Pawirosoemardjo, 2004). Sasaran utama serangan patogen adalah pada daun karet muda (Febbiyanti \& Kusdiana, 2012). Penyakit gugur daun Colletotrichum dipengaruhi oleh kelembaban nisbi udara, curah hujan yang tinggi, serta hujan yang besar dapat membantu timbul dan berkembangnya penyakit. Selain itu kondisi tanaman dan jenis atau klon tanaman juga berpengaruh terhadap serangan penyakit (Pawirosoemardjo, 2004).

Pengendalian penyakit gugur daun Colletotrichum pada pertanaman karet dewasa sulit dilakukan karena ukuran pohon yang sudah tinggi sehingga sulit untuk dijangkau. Pengendalian menggunakan fungisida efisien dilakukan dengan aplikasi dari udara, tetapi frekuensi pengendalian mungkin terbatas dan biaya pengendalian yang cukup tinggi. Sehingga aplikasi fungisida yang efisien pun sulit untuk dilakukan (Guyot et al., 2001).

Pada dasarnya semua spesies tanaman menunjukkan variasi genetik yang diwariskan untuk ketahanan terhadap berbagai penyakit tanaman. Pengendalian penyakit dengan menggunakan genetika dapat menjadi suatu alternatif daripada menggunakan pengendalian secara kimiawi yang berulang dan mahal (Jones et al., 2014). Gen resistensi penyakit tanaman memiliki kemampuan untuk mendeteksi serangan patogen dan memfasilitasi serangan balik terhadap patogen. Banyak tanaman resisten telah digunakan dan secara efisien mengendalikan penyakit tanaman yang disebabkan oleh patogen
(Gururani et al., 2012). Oleh karena itu, para pemulia tanaman terus melakukan penelitian untuk mendapatkan klon-klon karet baru yang lebih produktif dan lebih resisten terhadap serangan penyakit tanaman. Setelah mendapatkan klon-klon karet baru, maka pengujian keragaman resistensi tanaman terhadap serangan penyakit pun harus dilakukan. Penelitian ini dilakukan untuk menguji ketahanan tanaman karet klon IRR seri 300 terhadap penyakit gugur daun Colletotrichum, sehingga hasil dari penelitian ini dapat dijadikan suatu acuan untuk melakukan penanaman karet dengan menggunakan klon yang tahan penyakit gugur daun Colletotrichum.

\section{BAHAN DAN METODE}

Penelitian dilaksanakan di Laboratorium Proteksi Tanaman, Rumah Kaca, dan Kebun Percobaan Balai Penelitian Sembawa mulai Januari sampai dengan Agustus 2017. Penelitian terdiri dari tiga kegiatan yaitu (a) pengujian resistensi daun karet klon IRR seri 300 terhadap $C$. gloeosporioides di laboratorium, (b) pengujian resistensi klon IRR seri 300 terhadap C. gloeosporioides pada bibit di rumah kaca, dan (c) pengamatan resistensi klon IRR seri 300 di lapangan. Adapun rincian metode penelitian sebagai berikut:

\section{Pengujian Resistensi Klon IRR Seri 300 terhadap C. gloeosporioides di Laboratorium}

\section{a. Persiapan Biakan Isolat C. gloeosporioides}

Biakan isolat C. gloeosporioides diperoleh dari daun yang terserang penyakit gugur daun Colletotrichum di lapangan yang dibiakan di atas media Potato Dextrose Agar (PDA). Daun sakit yang digunakan berasal dari klon karet RRIM 600 (CG-RRIM 600), GT 1 (CG-GT 1), dan PR 303 (CG-PR 303).

\section{b. Produksi Konidia C. gloeosporioides}

Produksi konidia C. gloeosporioides dilakukan dengan mengambil konidia patogen dari biakan murni berumur tujuh hari menggunakan kuas. Konidia tersebut dimasukkan ke dalam Erlenmeyer yang 
telah berisi air steril, kemudian disaring menggunakan kassa untuk memisahkan konidia dengan media agar. Konsentrasi konidia dihitung menggunakan haemocytometer di bawah mikroskop.

\section{c. Aplikasi Konidia C. gloeosporioides pada Daun Karet}

Pengujian resistensi klon IRR seri 300 terhadap penyakit gugur daun Colletotrichum menggunakan rancangan acak lengkap dengan dua faktor, masingmasing perlakuan dilakukan ulangan sebanyak tiga kali. Dua faktor perlakuan yang digunakan dalam percobaan yaitu:

1. Faktor perlakuan klon, terdiri dari 26 jenis klon, yaitu: IRR 300, IRR 301, IRR 302, IRR 303, IRR 304, IRR 305, IRR 306, IRR 307, IRR 308, IRR 309, IRR 310, IRR 311, IRR 312, IRR 313, IRR 314, IRR 315, IRR 316, IRR 317, IRR 318, IRR 319, IRR 321, IRR 323, serta sebagai pembanding menggunakan klon GT 1, RRIM 600, RRIC 100, dan TJIR 1.
2. Faktor isolat yaitu : CG-RRIM 600, CGGT 1, dan CG-PR 303.

Aplikasi konidia C. gloeosporioides dilakukan pada daun karet berwarna hijau muda berumur 3 minggu dengan memberi masing-masing daun sebanyak 4-6 tetes suspensi konidia. Konsentrasi konidia yang digunakan $10^{6}$ konidia/ml air (Gambar 1). Konsentrasi tersebut merupakan konsentrasi konidia optimum yang dapat menyebabkan perkembangan penyakit di daun karet (Sangu \& Muid, 2016). Selanjutnya daun diinkubasi pada suhu kamar selama tujuh hari.

\section{d. Pengamatan dan Analisa Data}

Pengamatan dilakukan dengan menghitung keparahan serangan penyakit pada daun setelah tujuh hari perlakuan. Pengamatan dilakukan dengan menggunakan skala serangan yang dikelompokkan pada Tabel 1 (Pawirosoemardjo, 1984).

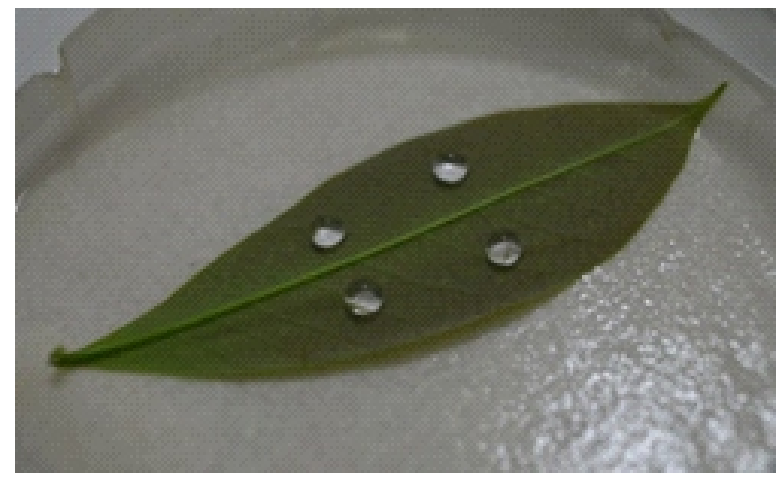

Gambar 1. Aplikasi konidia C. gloeosporioides pada daun karet

Figure 1. Application of $\mathrm{C}$. gloeosporioides conidia on rubber leaves

Tabel 1. Klasifikasi skala serangan C. gloeosporioides pada daun

Table 1. Classification of $\mathrm{C}$. gloeosporioides attacks scale on leaves

\begin{tabular}{cl}
\hline $\begin{array}{c}\text { Skor penyakit } \\
\text { Disease skore }\end{array}$ & \multicolumn{1}{c}{$\begin{array}{c}\text { Deskripsi } \\
\text { Description }\end{array}$} \\
\hline 0 & Tidak ada serangan \\
$1 \%-25 \%$ luasan daun terdapat miselium cendawan atau daun \\
berwarna kuning kecokelatan \\
$26 \%-50 \%$ luasan daun terdapat miselium cendawan atau daun \\
berwarna kuning kecokelatan \\
$51 \%-75 \%$ luasan daun terdapat miselium cendawan atau daun \\
3 & $\begin{array}{l}\text { berwarna kuning kecokelatan } \\
76 \%-100 \% \text { luasan daun terdapat miselium cendawan atau daun } \\
\text { berwarna kuning kecokelatan }\end{array}$ \\
\hline
\end{tabular}


Hasil pengukuran skala serangan dimasukkan dalam rumus Towsendt \& Hueberger, 1943 (Sinaga, 2006):

$\mathrm{KP}=\frac{\sum_{i=1}^{n} n \cdot v}{Z \cdot N} \times 100 \%$

Keterangan (Remarks):

KP : keparahan serangan penyakit;

$\mathrm{n}$ : jumlah tanaman berskala v;

$\mathrm{v}$ : skala ke-i; dan

$Z$ : nilai skor tertinggi.

$\mathrm{N}$ : jumlah tanaman yang diamati

Berdasarkan persentase keparahan penyakit tersebut, tingkat ketahanan masing-masing klon selanjutnya dikelompokkan seperti pada Tabel 2 (Pawirosoemardjo, 1984).

Interaksi antara klon dengan isolat dianalisis ANOVA dua faktor (klon*isolat) menggunakan program SAS (Statistical Analysis System).

\section{Pengujian Resistensi Klon IRR seri 300 terhadap C. gloeosporioides pada Bibit di Rumah Kaca}

Pengujian dilakukan pada bibit karet dalam polibeg berumur tiga bulan dengan menggunakan rancangan acak lengkap dua faktor dengan tiga ulangan. Faktor perlakuan yang digunakan adalah jenis klon karet dan jenis isolat C. gloeosporioides. Setiap ulangan terdiri dari tiga unit tangkai daun.

\section{a. Inokulasi Konidia Patogen pada Bibit Karet dalam Polibag}

Inokulasi dilakukan dengan menyemprotkan sebanyak satu $\mathrm{mL}$ inokulum konsentrasi $10^{6}$ konidia $/ \mathrm{mL}$ (Sangu \& Muid, 2016) dengan menggunakan sprayer pada permukaan daun tanaman. Daun yang digunakan merupakan daun muda (berwarna cokelat) berumur 2 minggu. Daun tersebut kemudian disungkup menggunakan kantong plastik transparan untuk mempertahankan kelembaban selama inkubasi. Empat hari setelah inkubasi, sungkup plastik dilepas dan dibiarkan selama delapan hari untuk diamati (Munir et al., 2009).

\section{b. Pengamatan dan Analisis Data}

Pengamatan virulensi isolat patogen ditentukan berdasarkan keparahan penyakit pada daun. Pengukuran keparahan serangan penyakit dilakukan 12 hari setelah inokulasi konidia. Pengamatan dilakukan dengan menggunakan skor penyakit seperti pada Tabel 1 dan hasil pengukuran skor penyakit dimasukkan dalam rumus Towsendt \& Hueberger (1943) dalam Sinaga (2006) seperti pada pengujian pertama. Berdasarkan hasil persentase keparahan penyakit tersebut, tingkat ketahanan klon dikelompokkan seperti pada Tabel 2 . Interaksi antara klon dengan isolat dianalisis ANOVA dua faktor (klon*isolat) menggunakan program SAS (Statistical Analysis System).

Tabel 2. Klasifikasi ketahanan klon berdasarkan keparahan penyakit Table 2. Classification of clone resistance based on diasese severity

\begin{tabular}{cl}
\hline $\begin{array}{c}\text { Keparahan penyakit } \\
\text { Disease severity }\end{array}$ & \multicolumn{1}{c}{ Klasifikasi } \\
Classification
\end{tabular}




\section{Pengamatan Resistensi Klon IRR seri 300 pada Tanaman Belum Menghasilkan di Lapangan}

Pengamatan resistensi klon IRR seri 300 terhadap penyakit gugur daun Colletotrichum dilakukan pada tanaman belum menghasilkan (TBM) dengan luasan satu hektar pada masing-masing klon. Pengamatan dilakukan secara visual dengan melihat persentase serangan penyakit pada tanaman. Pengamatan dilakukan dua kali per tahun pada bulan April dan Oktober.

\section{HASIL DAN PEMBAHASAN}

\section{Pengujian Resistensi Klon IRR Seri 300 terhadap C. gloeosporioides di Laboratorium}

Keparahan penyakit pada daun klon IRR seri 300 terhadap tiga isolat patogen C. gloeosporioides menunjukkan bahwa setiap klon memiliki tingkat ketahanan yang berbeda terhadap setiap isolat patogen yang digunakan. Perbedaan tersebut dapat terjadi karena adanya interaksi antara gen resisten tanaman inang (karet) dengan gen virulensi patogen (Flor, 1971). Hal tersebut sejalan dengan penelitian sebelumnya yang menyatakan bahwa setiap klon karet memiliki tingkat ketahanan yang bervariasi terhadap isolat C. gloeosporioides (Kusdiana \& Oktavia, 2014; Munir et al., 2009).

Hasil pengamatan keparahan penyakit klon karet IRR seri 300 terdapat delapan klon karet yang diuji merupakan klon yang tergolong sangat resisten, tujuh klon karet tergolong resisten, enam klon karet tergolong moderat, empat klon karet tergolong rentan, dan satu klon karet tergolong sangat rentan terhadap penyakit gugur daun Colletotrichum pada skala laboratorium. Pengujian terhadap 22 klon karet IRR seri 300 dan klon pembanding pada skala laboratorium menunjukkan bahwa klon karet dengan tingkat ketahanan paling tinggi adalah klon IRR 307 dengan keparahan penyakit sebesar $5,56 \%$ dan tingkat ketahanan paling rendah adalah klon IRR 305 dengan keparahan penyakit sebesar 88,89\% (Tabel 3).
Hasil perhitungan keparahan penyakit dari semua klon pada setiap isolat $C$. gloeosporioides berkisar antara 34,62\% $44,55 \%$ (Tabel 4). Ketiga isolat $C$. gloeosporioides tersebut memiliki nilai intensitas serangan penyakit yang cukup tinggi dengan nilai intensitas serangan penyakit paling tinggi adalah isolat $C$. gloeosporioides CG-PR 303. Hal ini dapat disebabkan karena ketiga isolat tersebut merupakan isolat yang memiliki tingkat virulensi tinggi (Kusdiana et al., 2017) dan ketiga klon tersebut telah ditanam dalam skala luas di perkebunan karet Indonesia sehingga diperkirakan patogen dari klon tersebut terdapat dalam jumah besar di alam. Menurut Kusdiana \& Febbiyanti (2016) semakin banyak jumlah konidia $C$. gloeosporioides yang tertangkap di udara maka sebanding dengan keparahan penyakit yang terjadi di lapangan.

\section{Pengujian Resistensi Klon IRR seri 300 terhadap Colletotrichum sp. pada Bibit di Rumah Kaca}

Hasil penelitian di rumah kaca menunjukkan adanya tingkat virulensi yang berbeda antar setiap jenis isolat terhadap keparahan penyakit setiap klon. Hal serupa sejalan dengan penelitian Kusdiana et al. (2017) yang menunjukkan bahwa setiap jenis klon memiliki tingkat ketahanan yang berbeda terhadap setiap jenis isolat patogen C. gloeosporioides pada pengujian skala rumah kaca. Perbedaan tersebut dapat terjadi karena adanya interaksi satu sama lain antara tanaman inang dan patogen. Gen avirulen yang sesuai dapat memulai reaksi hipersensitif (HR) yang menyebabkan ketidakcocokan dengan tanaman inang (Vale et al., 2001).

Tingkat ketahanan bibit karet klon IRR seri 300 hanya menunjukkan dua respon yang berbeda terhadap serangan penyakit gugur daun Colletotrichum yaitu ketahanan sangat resisten dan resisten (Tabel 5). Tingginya resistensi pada klon IRR seri 300 diduga karena patogen C. gloeosporioides belum terstimulasi membentuk isolat yang virulen dan tekanan seleksi terhadap patogen untuk membentuk ras baru belum terjadi karena luas pertanaman klon karet IRR seri 300 relatif masih terbatas di lapangan. 
Tabel 3. Tingkat ketahanan klon IRR seri 300 berdasarkan keparahan penyakit pada skala laboratorium

Table 3. Resistance level of IRR series 300 rubber clones based on disease severity on laboratory scale

\begin{tabular}{|c|c|c|c|}
\hline No. & $\begin{array}{l}\text { Klon } \\
\text { Clone }\end{array}$ & $\begin{array}{l}\text { Keparahan penyakit }(\%)^{*} \\
\text { Disease severity }\end{array}$ & $\begin{array}{l}\text { Tingkat resistensi } \\
\text { Resistance level }\end{array}$ \\
\hline 1 & IRR 300 & 33,33 hijk & resisten \\
\hline 2 & IRR 301 & $19,44 \mathrm{jklm}$ & sangat resisten \\
\hline 3 & IRR 302 & 36,11 hij & resisten \\
\hline 4 & IRR 303 & 61,11 bcde & Rentan \\
\hline 5 & IRR 304 & 41,67 fghi & moderat \\
\hline 6 & IRR 305 & 88,89 a & sangat rentan \\
\hline 7 & IRR 306 & 55,56 cdefg & moderat \\
\hline 8 & IRR 307 & $5,56 \mathrm{~m}$ & sangat resisten \\
\hline 9 & IRR 308 & 38,89 ghi & resisten \\
\hline 10 & IRR 309 & $11,11 \mathrm{~lm}$ & sangat resisten \\
\hline 11 & IRR 310 & $11,11 \mathrm{~lm}$ & sangat resisten \\
\hline 12 & IRR 311 & $11,11 \mathrm{~lm}$ & sangat resisten \\
\hline 13 & IRR 312 & $72,22 \mathrm{abc}$ & rentan \\
\hline 14 & IRR 313 & 27,78 ijkl & resisten \\
\hline 15 & IRR 314 & $77,78 \mathrm{ab}$ & rentan \\
\hline 16 & IRR 315 & 38,89 ghi & resisten \\
\hline 17 & IRR 316 & $16,67 \mathrm{klm}$ & sangat resisten \\
\hline 18 & IRR 317 & 44,44 efghi & moderat \\
\hline 19 & IRR 318 & $16,67 \mathrm{klm}$ & sangat resisten \\
\hline 20 & IRR 319 & $66,67 \mathrm{bcd}$ & rentan \\
\hline 21 & IRR 321 & $36,11 \mathrm{hij}$ & resisten \\
\hline 22 & IRR 323 & 50,00 defgh & moderat \\
\hline 23 & GT 1 & 44,44 efghi & moderat \\
\hline 24 & RRIM 600 & $27,78 \mathrm{ijkl}$ & resisten \\
\hline 25 & RRIC 100 & $16,67 \mathrm{klm}$ & sangat resisten \\
\hline 26 & TJIR 1 & 58,33 cdef & moderat \\
\hline
\end{tabular}

* Angka-angka yang diikuti huruf yang sama pada kolom yang sama tidak berbeda nyata berdasarkan Uji Jarak Berganda Duncan 5\%

* Number followed with the same letter in the same coloumn are not significantly different $(P<0,05)$

Tabel 4. Keparahan penyakit gugur daun Colletotrichum pada berbagai klon karet IRR seri 300 terhadap tiga isolat C. gloeosporioides

Table 4. Colletotrichum leaffall disease severity of IRR series 300 rubber clones to three of C. gloeosporioides isolates

\begin{tabular}{cc}
\hline $\begin{array}{c}\text { Isolat C. gloeosporioides } \\
\text { C. gloeosporioides isolates }\end{array}$ & $\begin{array}{c}\text { Keparahan penyakit } \\
\text { Disease severity } \\
(\%)\end{array}$ \\
\hline CG-RRIM 600 & $34,62 \mathrm{~b}$ \\
CG-GT 1 & $37,18 \mathrm{~b}$ \\
CG-PR 303 & $44,55 \mathrm{a}$ \\
\hline
\end{tabular}

\footnotetext{
*Angka-angka yang diikuti huruf yang sama pada kolom yang sama tidak berbeda nyata berdasarkan Uji Jarak Berganda Duncan 5\%

*Number followed with the same letter in the same coloumn are not significantly different $(P<0,05)$
} 
Tabe15. Keparahan penyakit gugur daun Colletotrichum pada klon karet IRR seri 300 skala rumah kaca

Table 5. Colletotrichum leaf fall disease severity of IRR series 300 rubber clones on greenhouse scale

\begin{tabular}{|c|c|c|c|}
\hline No. & $\begin{array}{l}\text { Klon } \\
\text { Clone }\end{array}$ & $\begin{array}{l}\text { Keparahan penyakit }(\%)^{*} \\
\text { Disease severity }\end{array}$ & $\begin{array}{l}\text { Tingkat resistensi } \\
\text { Resistance level }\end{array}$ \\
\hline 1 & IRR 300 & $25,62 \mathrm{ab}$ & resisten \\
\hline 2 & IRR 301 & $17,44 \mathrm{~b}$ & sangat resisten \\
\hline 3 & IRR 302 & $23,46 \mathrm{ab}$ & resisten \\
\hline 4 & IRR 303 & $20,99 \mathrm{ab}$ & sangat resisten \\
\hline 5 & IRR 304 & $38,49 \mathrm{a}$ & resisten \\
\hline 6 & IRR 305 & $17,90 \mathrm{ab}$ & sangat resisten \\
\hline 7 & IRR 306 & $23,46 \mathrm{ab}$ & resisten \\
\hline 8 & IRR 307 & $23,77 \mathrm{ab}$ & resisten \\
\hline 9 & IRR 308 & $20,06 \mathrm{ab}$ & sangat resisten \\
\hline 10 & IRR 309 & $26,54 a b$ & resisten \\
\hline 11 & IRR 310 & $9,88 \mathrm{~b}$ & sangat resisten \\
\hline 12 & IRR 311 & $20,99 a b$ & sangat resisten \\
\hline 13 & IRR 312 & $18,83 \mathrm{ab}$ & sangat resisten \\
\hline 14 & IRR 313 & $21,30 \mathrm{ab}$ & resisten \\
\hline 15 & IRR 314 & $26,54 \mathrm{ab}$ & resisten \\
\hline 16 & IRR 315 & $25,93 \mathrm{ab}$ & resisten \\
\hline 17 & IRR 316 & $17,90 \mathrm{ab}$ & sangat resisten \\
\hline 18 & IRR 317 & $22,22 \mathrm{ab}$ & resisten \\
\hline 19 & IRR 318 & $10,71 \mathrm{~b}$ & sangat resisten \\
\hline 20 & IRR 319 & $22,53 \mathrm{ab}$ & resisten \\
\hline 21 & IRR 321 & $26,85 a b$ & resisten \\
\hline 22 & IRR 323 & $15,43 \mathrm{~b}$ & sangat resisten \\
\hline 23 & GT 1 & $27,16 \mathrm{ab}$ & resisten \\
\hline 24 & RRIM 600 & $15,74 \mathrm{~b}$ & sangat resisten \\
\hline 25 & RRIC 100 & $14,20 \mathrm{~b}$ & sangat resisten \\
\hline 26 & TJIR 1 & $30,25 \mathrm{ab}$ & resisten \\
\hline
\end{tabular}

* Angka-angka yang diikuti huruf yang sama pada kolom yang sama tidak berbeda nyata berdasarkan Uji Jarak Berganda Duncan 5\%

* Number followed with the same letter in the same coloumn are not significantly different $(P<0,05)$

Selain klon IRR seri 300 terdapat empat klon pembanding yang juga memiliki tingkat ketahanan sangat resisten dan resisten. Hasil penelitian sebelumnya menunjukkan bahwa klon RRIM 600, GT 1, dan RRIC 100 memiliki tingkat ketahanan resisten terhadap penyakit gugur daun Colletotrichum pada pengujian skala rumah kaca (Kusdiana et al., 2017). Selain itu, Narayanan \& Mydin (2012) melaporkan bahwa klon RRIM 600 resisten terhadap penyakit gugur daun Colletotrichum. Klonklon pembanding yang sudah ditanam secara luas di lapangan tidak atau belum terserang penyakit gugur daun Colletotrichum kemungkinan secara genetik klon tersebut sangat tahan terhadap serangan penyakit gugur daun Colletotrichum dan ketahanan tersebut belum terpatahkan oleh isolat $C$. gloeosporioides.

Hasil perhitungan rata-rata keparahan penyakit semua klon pada setiap isolat berkisar antara $17,80 \%-26,08 \%$ dengan persentase tertinggi ditemukan pada isolat CG-PR 303 (Tabel 6). Pengaruh perlakuan spora terhadap intensitas penyakit menunjukkan bahwa spora $C$. gloeosporioides CG-PR 303 memiliki pengaruh paling besar dibanding jenis spora lainnya. Hal ini juga sejalan dengan hasil 
Tabel 6. Keparahan penyakit Colletotrichum berbagai klon karet IRR seri 300 terhadap tiga isolat $C$. gloeosporioides pada skala rumah kaca

Table 6. Colletotrichum leaffall disease severity of IRR series 300 rubber clones to three of C. gloeosporioides isolates on greenhouse scale

\begin{tabular}{cc}
\hline $\begin{array}{c}\text { Isolat C. gloeosporioides } \\
\text { C. gloeosporioides isolates }\end{array}$ & $\begin{array}{c}\text { Keparahan Penyakit } \\
\text { Disease severity } \\
(\%)\end{array}$ \\
\hline CG-RRIM 600 & $20,99 \mathrm{ab}$ \\
CG-GT 1 & $17,80 \mathrm{~b}$ \\
CG-PR 303 & $26,08 \mathrm{a}$ \\
\hline
\end{tabular}

* Angka-angka yang diikuti huruf yang sama pada kolom yang sama tidak berbeda nyata berdasarkan Uji Jarak Berganda Duncan 5\%

* Number followed with the same letter in the same coloumn are not significantly different $(P<0,05)$

penelitian Kusdiana et al. (2017) yang menunjukkan bahwa spora CG-PR 303 memiliki pengaruh paling besar terhadap keparahan penyakit pada klon karet skala rumah kaca, diikuti oleh spora CG-RRIM 600 dan CG-GT 1.

\section{Pengamatan Resistensi Klon IRR seri 300 pada Tanaman Belum Menghasilkan di Lapangan}

Pengamatan resistensi klon IRR seri 300 terhadap penyakit gugur daun Colletotrichum pada TBM di lapangan dilakukan secara visual pada 22 klon IRR seri 300 dan satu klon pembanding yaitu BPM 24 (Tabel 7).

Hasil pengamatan secara visual dengan melihat persentase serangan penyakit di lapangan menunjukkan bahwa klon IRR seri 300 memiliki tingkat ketahanan yang lebih baik terhadap serangan penyakit gugur daun Colletotrichum dibandingkan klon pembanding BPM 24 pada pengujian di Sembawa, Sumatera Selatan. Terdapat dua klon yang memiliki ketahanan sangat resisten yaitu klon IRR 302 dan IRR 306, namun terdapat satu klon yang memiliki ketahanan rentan yaitu klon IRR 314. Hasil pengamatan pada TBM karet klon IRR seri 300 di plot promosi Kebun Percobaan Sungei Putih, Sumatera Utara juga menunjukkan hasil yang sama bahwa klon IRR seri 300 memiliki resistensi tinggi (tahan) terhadap penyakit gugur daun Colletotrichum (Woelan et al., 2009; Woelan., 2012). Tingginya tingkat ketahanan klon IRR seri 300 terhadap penyakit gugur daun Colletotrichum memberikan indikasi bahwa klon-klon tersebut cukup baik ditanam dalam skala luas.

Beberapa klon menunjukkan tingkat ketahanan yang berbeda terhadap penyakit gugur daun Colletorichum pada berbagai tingkat pengujian seperti klon IRR 303, IRR 304, IRR 305, IRR 306, IRR 312, IRR 314, IRR 317, IRR 319, dan IRR 323. Pengujian pada skala laboratorium menunjukkan bahwa klon-klon tersebut memiliki tingkat ketahanan moderat dan rentan, namun pengujian pada skala rumah kaca dan pengamatan di lapangan menunjukkan bahwa klon-klon tersebut resisten terhadap penyakit gugur daun Colletotrichum. Begitu juga sebaliknya, pengujian di tingkat rumah kaca menunjukkan suatu klon tahan seperti yang ditemukan pada klon IRR 314. Pada pengujian resistensi tanaman perbedaan ini seringkali terjadi karena adanya berbagai faktor yang mempengaruhi tingkat keparahan suatu penyakit pada suatu lokasi yaitu genetik tanaman, genetik patogen, dan lingkungan. Hal yang sama juga dilaporkan oleh Munir et al. (2009) pada pengujian resistensi klon IRR seri 100 terhadap penyakit gugur daun Colletotrichum terdapat perbedaan ketahanan antara pengujian di laboratorium dengan di lapangan.

\section{KESIMPULAN DAN SARAN}

Hasil pengujian menunjukkan bahwa klon seri IRR 300 memiliki tingkat ketahanan tinggi terhadap serangan penyakit gugur daun Colletotrichum. Resistensi daun terhadap C. gloeosporioides di laboratorium, pengujian keparahan 
Tabel 7. Tingkat Resistensi TBM Klon IRR seri 300 terhadap Penyakit Gugur Daun Colletotrichum

Table 7. Resistance Level of IRR 300 series Immature Rubber Plants to Corynespora Leaf Fall Disease

\begin{tabular}{|c|c|c|}
\hline No. & $\begin{array}{l}\text { Klon } \\
\text { Clone }\end{array}$ & $\begin{array}{c}\text { Tingkat resistensi } \\
\text { Resistance level }\end{array}$ \\
\hline 1 & IRR 300 & resisten \\
\hline 2 & IRR 301 & resisten \\
\hline 3 & IRR 302 & sangat resisten \\
\hline 4 & IRR 303 & resisten \\
\hline 5 & IRR 304 & resisten \\
\hline 6 & IRR 305 & resisten \\
\hline 7 & IRR 306 & sangat resisten \\
\hline 8 & IRR 307 & resisten \\
\hline 9 & IRR 308 & resisten \\
\hline 10 & IRR 309 & resisten \\
\hline 11 & IRR 310 & resisten \\
\hline 12 & IRR 311 & resisten \\
\hline 13 & IRR 312 & resisten \\
\hline 14 & IRR 313 & resisten \\
\hline 15 & IRR 314 & rentan \\
\hline 16 & IRR 315 & resisten \\
\hline 17 & IRR 316 & resisten \\
\hline 18 & IRR 317 & resisten \\
\hline 19 & IRR 318 & resisten \\
\hline 20 & IRR 319 & resisten \\
\hline 21 & IRR 321 & resisten \\
\hline 22 & IRR 323 & resisten \\
\hline 23 & BPM 24 & rentan \\
\hline
\end{tabular}

penyakit terhadap spora $C$. gloeosporioides pada bibit karet dalam polibeg, serta pengamatan pada TBM klon IRR seri 300 di lapangan menunjukkan klon IRR 300, IRR 301, IRR 302, IRR 307, IRR 308, IRR 309, IRR 310, IRR 311, IRR 313, IRR 315, IRR 316, IRR 318, dan IRR 321 memiliki tingkat ketahanan lebih tinggi terhadap penyakit gugur daun Colletotrichum dibandingkan klon IRR seri 300 lainnya. Sedangkan ketiga isolat C. gloeosporioides yang digunakan memiliki pengaruh nyata terhadap tingkat keparahan penyakit baik pada pengujian daun di laboratorium maupun pada pengujian bibit karet dalam polibag di rumah kaca. Isolat CG-PR 303 memiliki tingkat virulensi paling tinggi dibandingkan isolat CG-RRIM 600 dan CG-GT 1.

\section{DAFTAR PUSTAKA}

Febbiyanti, T. R., \& Kusdiana, A. P. J. (2012). Pengaruh infeksi jamur Colletotrichum gloeosporioides terhadap kerusakan daun tanaman karet. Prosiding Konferensi Nasional Karet (pp. 251258). Bogor: Pusat Penelitian Karet.
Flor, H. H. (1971). Current status of the genefor-gene concept. Annual Review of Phytopathology, 9, 275-296. doi: 10.1146/annurev.py.09.090171.0014 23.

Gururani, M. A., Venkatesh, J., Upadhyaya, C. P., Nookaraju, A., Pandey, S. K., \& Park, S. W. (2012). Plant disease resistance genes: Current status and future directions. Plant Pathology, 78, 51-65. doi: 1 0.1016/j.pmpp. 2012.01.002.

Guyot, J., Omanda, E. N., Ndoutoume, A., Otsaghe, A. M., Enjalric, F., \& Assoumou, H. G. N. (2001). Effect of controlling Colletotrichum leaf fall of rubber tree on epidemic development and rubber production. Crop Protection, 20, 581-590. doi: 10.1016/S0261-2194(01)00027-8.

Jayasinghe, C. K., Fernando, T. H. P. S, \& Priyanka, U. M. S. (1997). Colletotrichum acutatum is the main cause of Colletotrichum leaf disease of rubber in Sri Lanka. Mycopathologia, $137,53-56$. doi: 10.1023/A: 1006850119146. 
Jones, J. D. G., Witek, K., Verweij, W., Jupe, F., Cooke, D., Dorling, S., \& et al. (2014). Elevating crop disease resistance with cloned genes. Philosophical Transactions of the Royal Society B: Biological Sciences, 369(1639), 20130087-20130087. doi:10.1098/rstb.2013.0087.

Kusdiana, A. P. J., \& Febbiyanti, T. R. (2016). Pengaruh cuaca terhadap perkembangan spora udara Colletotrichum gloeosporioides penyebab penyakit gugur daun tanaman karet. Prosiding Seminar Nasional Dies Natalis ke-53 Fakultas Pertanian Universitas Sriwijaya (pp. Pertanian 11-21). Palembang: Fakultas Pertanian, Universitas Sriwijaya.

Kusdiana, A. P. J., \& Oktavia, F. (2014). Resistensi plasma nutfah IRRDB 1981 terhadap penyakit gugur daun Colletotrichum. Prosiding Seminar Dies Natalis Fakultas Pertanian Universitas Sriwijaya ke-51 tahun 2014 (pp. 4855). Palembang: Fakultas Pertanian, Universitas Sriwijaya.

Kusdiana, A. P. J., Syafaah, A., \& Febbiyanti, T. R. (2017). Resistance of rubber clones recommended in Indonesia to Corynespora and Colletotrichum leaf fall diseases. Proceedings of International Rubber Conference 2017 (pp. 811-821). Bogor: Indonesian Rubber Research Institute.

Munir, M., Suryaningtyas, H., Situmorang, A., \& Febbiyanti, T. R. (2009). Resistensi klon IRR seri 100 terhadap penyakit gugur daun Corynespora dan Colletotrichum. Prosiding Lokakarya Nasional Pemuliaan Tanaman Karet (pp. 262-268). Bogor: Pusat Penelitian Karet.

Narayanan, C. \& Mydin, K. K. (2012). Breeding for disease resistance in Hevea spp. - status, potential threats, and possible strategies. Proceedings of the 4th International Workshop on GenetiCG of Host - Parasite Interactions in Forestry (pp. 240-251). Albany, CA: Pacific Southwest Research Station, Forest Service, U.S. Department of Agriculture.
Pawirosoemardjo, S. (2004). Manajemen pengendalian penyakit penting dalam upaya mengamankan target produksi karet nasional tahun 2020. Prosiding Pertemuan Teknis (pp. 21-45). Palembang: Pusat Penelitian Karet.

Pawirosoemardjo, S. (1984). Beberapa aspek hubungan patogen-inang dalam penyakit gugur daun Colletotrichum pada Hevea brasiliensis Muell Arg. (Disertasi, Institut Pertanian Bogor, Indonesia). Diakses dari https://repository.ipb.ac.id

Sangu, S. S., \& Muid, S. (2016). Effects of Inoculum Concentrations of Colletotrichum gloeosporioides on Disease Development and Severity on Leaves of Rubber Tree (Hevea brasiliensis). Borneo Journal of Resource Science and Technology, 6(1), 50-54.

Shufen, F., Gang, G., \& Fucong, Z. (1999). General situation of anthracnose of rubber trees and its researches in China. Proceedings of IRRDB Symposium 1999 (pp. 288-297). Hainan: Hainan Publishing House.

Sinaga, M. S. (2006). Dasar-Dasar Ilmu Penyakit Tumbuhan. Jakarta: Penebar Swadaya.

Vale, F. X. R. D., Parlevliet, J. E., \& Zambolim, L. (2001). Concepts in plant disease resistance. Fitopatologia Brasileira, 26(3), 577-589. d o i : 10 . $1590 /$ s 0100 41582001000300001

Woelan, S., Aidi-Daslin, Lasminingsih, M., \& Suhendry, I. (2009). Evaluasi keragaan klon karet IRR seri 200 dan 300 pada tahap pengujian. Prosiding Lokakarya Nasional Pemuliaan Tanaman Karet (pp. 84-106). Bogor: Pusat Penelitian Karet.

Woelan, S., Sayurandi., \& Pasaribu, S. A. (2012). Keragaan klon IRR seri 300 dan 400 di pengujian plot promosi. Warta Perkaretan, 31 (1), 1-9. 